\title{
Irrigation management practices in nectarine fruit quality at harvest and after cold storage
}

\author{
María R. Conesa ${ }^{1}$, Wenceslao Conejero ${ }^{1}$, Juan Vera $^{1}$, Vicente Agulló ${ }^{2}$, Cristina

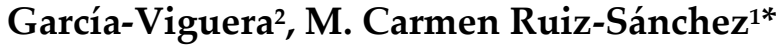

${ }^{1}$ Irrigation Department 2 Phytochemistry and Healthy Foods Lab, Food Science and Technology Department, CEBAS-CSIC, Campus de Espinardo 25, 30100 Murcia, Spain

Number of text pages: 32

Number of Tables: 6

Number of Figures: 5

${ }^{*}$ Corresponding author:

M.C. Ruiz-Sánchez, mcruiz@cebas.csic.es

Irrigation Department, Centro de Edafología y Biología Aplicada del Segura (CEBAS-CSIC), Campus de Espinardo 25, 30100 Murcia, Spain.

\begin{abstract}
This work aimed to ascertain the effects of different irrigation management practices on yield, fruit quality (nutritional and sensorial) and storage performance of early-maturing nectarine fruits during three consecutive growing seasons (2016/2017-2018/2019) under Mediterranean conditions. Three irrigation treatments were studied: two based on maintaining non-limiting soil water conditions (100\% crop evapotranspiration, ETc) with one (T-Single) or two (T-Double) lines of emitters; and one based on volumetric soil water content (VSWC) threshold values (T-Auto). Despite the greater wetted surface in the T-Double treatment, a mild plant water deficit was observed during the post-harvest period, which did not significantly affect the yield and nectarine fruit quality. The T-Auto irrigation based on VSWC, which received $43 \%$ less water than the T-Single treatment, caused a moderate water deficit, without yield penalty in any of the growing seasons studied and an increase in the water use efficiency of $34 \%$ respect to the T-Single treatment. Furthermore, nectarine fruits from the T-Auto treatment had higher TSS levels ( ${ }^{\circ}$ Brix) at harvest. There were no significant differences in the physico-chemical quality among treatments after 10 days of cold storage $\left(0^{\circ} \mathrm{C}\right)$ plus 5 days of shelf-life $\left(15^{\circ} \mathrm{C}\right)$, showing fruits from the T-Single treatment the highest weight loss
\end{abstract}


values. The use of precise agronomic criteria with soil water sensors is an avantgarde alternative for irrigation scheduling compared to the conventional ETcbased irrigation that improved water use efficiency and contributed to the sustainability of agriculture. The T-Double treatment has not provided any advantage in terms of production and quality compared to the T-Single treatment.

Keywords: Automated irrigation, bioactive phytochemicals, drip irrigation, flavonoids, sensory analysis, weight loss

\section{INTRODUCTION}

Nectarine (Prunus persica (L.) Batsch) fruits unlike peaches are characterised by having smooth skin and attractive red colour that makes them highly appreciate by consumers worldwide. Furthermore, these fruits have proved to be a great source of bioactive compounds (such as (poly)phenolic) responsible for their antioxidant and nutritional properties, as well as their attractive red colour (Falagán et al., 2015a). In this aspect, the content of bioactive compounds should be included as an important factor in breeding programs to obtain new genotypes or new sustainable agronomic techniques that could enhance these bioactives (Legua et al., 2011; Di Vaio et al., 2015).

Under Mediterranean conditions the cultivation of early maturing varieties, whose harvest date lasted from the end of April to the beginning of May (Conesa et al., 2019a), has increased in recent years since less extreme climate prevailing during these months, makes it possible to reduce water consumption (Ruiz-Sánchez et al., 2018). Additionally, they are considered a profitable alternative to late-maturing varieties, as they are the first to go to market, as they get better export prices.

According to Mounzer et al. (2008), the fruit development of an earlymaturing Prunus sp. cultivar has a mean duration of 89 days from full bloom. As a result, harvested fruits might have low total soluble solids content (TSS < $10{ }^{\circ}$ Brix), high titratable acidity and excessive firmness what might affect the consumer acceptance (Falagán et al., 2016). To be successful from a market perspective, early-maturing nectarine fruits need to have equal or higher consumer acceptance as eating properties and visual appearance than standards cultivars (Kyriacou and Rouphael, 2018).

One of the main advantages of early-maturing cultivars is that the fruit growth stages, when uppermost water requirements occurred (defining a critical period for water deficits) coincide with low evaporative demand conditions. Thus, it is possible to reduce the amount of irrigation applied in 
those cultivars growing under Mediterranean climate, where water is a limiting factor for crop production (Ruiz-Sánchez et al., 2018). In this sense, Vera et al. (2019) reported that the annual water requirements of early-maturing nectarine trees cultivated in the agro-climatic region of Murcia is about 6,600 $\mathrm{m}^{3} \mathrm{ha}^{-1}$.

The effects of climate change on water resources in the Mediterranean Basin are related both to the increase in evaporation volumes and the reduction in the soil water content (CIHEAM, 2010). In this sense, the Mediterranean agriculture, which is the biggest water consuming activity of the area, needs to confront this situation, adopting not only efficient technological tools but also water-saving strategies to maximize water use efficiency that requires the accuracy knowledge of soil-and plant water status (Katerji et al., 2008; Fernández-García et al., 2020).

One of the key strategies used for improving water productivity is the Regulated Deficit Irrigation (RDI) developed in Australia by Chalmers et al., (1981). Adoption of RDI to schedule irrigation in orchards can be counted as an efficient strategy for water saving and to limit the plant growth of excessively vigorous fruit trees but without penalizing fruit productivity and quality (RuizSánchez et al., 2010; Chai et al., 2016; Pérez-Pastor et al., 2016). In earlymaturing varieties, water restrictions may be applied during the post-harvest period, when water stress has no influence on fruit growth, but only to extent that any limitation of shoot growth and the reserves gain for the trunk does not adversely affect the productivity of the next year (Mounzer et al., 2008; de la Rosa et al., 2016; Ruiz-Sánchez et al., 2018). Moreover, nectarine quality attributes are reported to be influenced by RDI strategies at harvest and during cold storage (de la Rosa et al., 2015; Falagán et al., 2014, 2015a,b). Previous studies have found an increase in some health-promoting compounds when nectarines were subjected to RDI because of the activation of specific metabolic pathways that allow their synthesis. For instance, Falagán et al. (2015a) reported that RDI nectarines had high levels of (poly)phenolic compounds than fruits from the well-irrigated treatment.

Drip irrigation is generally thought to be a very efficient irrigation technique easy to handle the three main queries: when to irrigate, how much water to apply and where to apply it, being the most widely used method for irrigating crops, specially under semi-arid conditions (Fereres and Soriano, 2007; Fernández-García et al., 2020). The basic concept underlying drip irrigation is to keep a bulb of soil moist so that plant roots can absorb water. The volume and shape of the wet bulb of each emitter are a function of the soil characteristics (texture and hydraulic conductivity) and the discharge rate of the emitter (Vera and De la Peña, 1997; Ayars et al., 2007). However, the number of the water emission points over the soil surface may also have an influence on plant growth. 
For irrigation of stone fruits orchard, as in the case of nectarine trees, growers generally use one line of emitters per tree row because of the cheaper cost of installation. However, we hypothesised that the same water volume applied with two lines of emitters may influence the soil moisture pattern, widening the wet bulbs, which would avoid salts accumulation, limiting water losses in depth, and improving the water use efficiency. Furthermore, the integration of new technologies into drip irrigation management, for instance using soil moisture sensors, is a major challenge which provides the irrigation doses being automatically adjusted in accordance with the information received from the agronomic criteria. Then, it can emulate the expert decision-making process without human intervention (Conesa et al., 2019b; Vera et al., 2019).

Up to our knowledge no studies are available in the literature that jointly addressed the effects of the number of the water emission points and automated drip irrigation on fruit tree performance and fruit quality. For these reasons, the objectives of this study were: (i) to evaluate during three consecutive growing seasons the effects of different irrigation practices on plant-soil water status and yield of early-maturing nectarine trees under Mediterranean conditions, and (ii) to assess the nectarine fruit quality (including nutritional, and sensorial analysis) at harvest, after cold storage and subsequent shelf-life periods in the different irrigation treatments. The drip irrigation management practices consisted of: two treatments (based on conventional crop evapotranspiration, ETc), with one or two lines of emitters, and one soil water sensor-based automated treatment.

\section{MATERIALS AND METHODS}

\subsection{Experimental field conditions}

The experiment was carried out during three consecutive growing seasons 2016/2017, 2017/2018 and 2018/2019 in a 0.5 ha plot of adult earlymaturing nectarine trees [Prunus persica (L.) Batsch cv. Flariba, on GxN-15 rootstock], spaced $6.5 \mathrm{~m} \times 3.5 \mathrm{~m}$ and trained to an open-centre canopy. The plot was located at the CEBAS-CSIC experimental field station in Santomera, Murcia, Spain (38 $06^{\prime} 31^{\prime \prime} \mathrm{N}, 1^{\circ} 02^{\prime} 14^{\prime \prime} \mathrm{W}, 110 \mathrm{~m}$ altitude). The soil in the 0-0.5 $\mathrm{m}$ layer was highly calcareous ( $45 \%$ calcium carbonate), with a clay loam texture (clay fraction: $41 \%$ illite, $17 \%$ smectite, and $30 \%$ palygorskite), low organic matter content $(1.3 \%)$, and a cationic exchange capacity of $97.9 \mathrm{mmol}$ $\mathrm{kg}^{-1}$. The average bulk density was $1.43 \mathrm{~g} \mathrm{~cm}^{-3}$. The volumetric soil water content (VSWC) at field capacity and permanent wilting point were 0.29 and $0.14 \mathrm{~m}^{3} \mathrm{~m}^{-3}$, respectively. Irrigation water, from Tagus-Segura transfer system had an average electrical conductivity $\left(\mathrm{EC}_{25}{ }^{\circ} \mathrm{C}\right)$ of $1.3 \mathrm{dS} \mathrm{m} \mathrm{m}^{-1}$ and $\mathrm{pH}$ around 8 . Trees were fertilised with 94-64-124 UF year ${ }^{-1}$ of $\mathrm{N}, \mathrm{P}_{2} \mathrm{O}_{5}$ and $\mathrm{K}_{2} \mathrm{O}$, respectively, and applied through the drip irrigation system (Vera and De la Peña, 1994). 
Meteorological data were recorded by an automated weather station located at the CEBAS-CSIC experimental field station (http://www.cebas.csic.es/general spain/est meteo.html) at $0.25 \mathrm{~km}$ from the nectarine orchard, which read values every $5 \mathrm{~min}$ and recorded the averages every $15 \mathrm{~min}$. The climate of the area was typically Mediterranean, with an average annual rainfall of $342 \mathrm{~mm}$ mainly concentrated during the autumnwinter season, and annual reference crop evapotranspiration (ETo) of 1,105.3 $\mathrm{mm}$ (Table 1). Maximum air temperatures were above $38^{\circ} \mathrm{C}$ during the summer and the minimum temperature $\left(-1.1^{\circ} \mathrm{C}\right)$ was recorded in January (data not shown).

Standard cultural practices (including pest control) were the same for all the trees of the experiment and were carried out by the technicians following usual criteria for the area. The phenological stages corresponded to those of early-maturing Prunus cultivars, as described in Mounzer et al. (2008), with full bloom occurring at the end of January and fruit ripening on early May. Fruits were hand-thinned by March to leave $0.25 \mathrm{~m}$ between them (commercial crop load) and the trees were pruned annually during dormancy period, in December.

\subsection{Irrigation treatments}

The experiment involved three different irrigation management treatments: two based on traditional crop evapotranspiration (ETc) calculations, and one automated irrigation treatment based on soil water sensors. Each growing season was divided into two periods: post-harvest (from May to October) and pre-harvest, the period corresponded with fruit growth (from March to May, next year):

(i) Single-line treatment (T-Single): irrigated at 100\% ETc during the whole season, to avoid limiting soil water conditions, with onesingle drip line per tree row and four pressure-compensated emitters $\left(4 \mathrm{~L} \mathrm{~h}^{-1}\right)$ per tree, located 0.5 and $1.3 \mathrm{~m}$ from tree trunk to both sides of the trees. ETc was estimated as the product of crop reference evapotranspiration (ETo) from Penman-Monteith equation (Allen et al., 1998) and local crop coefficient (Kc) obtained in the same experimental orchard (Abrisqueta et al., 2013).

(ii) Double-line treatment (T-Double): irrigated at 100\% ETc during the whole season with two drip lines per tree row (1 m apart) with 8 pressure-compensated emitters $\left(4 \mathrm{~L} \mathrm{~h}^{-1}\right)$ each per tree, located 0.5 and $1.3 \mathrm{~m}$ from tree trunk axis to both sides of the trees.

(iii) Automated treatment (T-Auto): irrigated automatically by monitoring the VSWC with encapsulated multi-depth EnviroScan ${ }^{\circledR}$ (Sentek Sensor Technologies, Stepney, Australia) 
capacitance probes.. Four PVC access tubes were installed $0.1 \mathrm{~m}$ from the emitter located close $(50 \mathrm{~cm})$ to the tree trunk in four representative trees, one of each replication. Each capacitance probe had sensors fitted at $0.1,0.3,0.5$, and $0.7 \mathrm{~m}$ depth, and was connected to a radio transmission unit. Values were read every 5 min and the average recorded every $15 \mathrm{~min}$. Probes were normalized and calibrated for a clay-loam soil (Evett et al., 2006; Abrisqueta et al., 2012; Vera et al., 2019.The VSWC threshold values were based on Management Allowed Depletion (MAD) values which were adjusted for the different phenological stages of the cultivar studied according to their water stress sensitivity for regulated deficit irrigation criteria (Ruiz-Sánchez et al., 2010; Conesa et al., 2019b). MAD was calculated from the following equation:

$$
\mathrm{MAD}=\alpha \times(\mathrm{FC}-\mathrm{WP}) \times \mathrm{z}
$$

[Equation 1]

where, FC is the field capacity, WP is the wilting point, $\alpha$ is the allowed soil water deficit proposed (Fig. 1), and $\mathrm{z}$ is soil depth ( $\mathrm{mm}$ ). The increased $\alpha$ during late post-harvest aimed to limit the excessive vegetative growth. Irrigation was automatically activated when VSWC values reached the threshold MAD value and stopped when FC was reached. Integrated 0-0.5 m VSWC values, coinciding with the effective root depth (Abrisqueta et al., 2017), were computed and used to act on electro-hydraulic valves by means of a real-time telemetry system. Automation was supported by addVANTAGE (by ADCON Telemetry), a webbased data visualization and processing platform of a wireless sensor network connected to radio-transmission units. The feedback routine for remotely triggering/stopping irrigation was configured on this platform under the 'condition' extension, acting on electro-valves. (Vera et al.,2019). Irrigation design and the distribution of emitters were the same as in the T-Single: one drip line with four emitters $\left(4 \mathrm{~L} \mathrm{~h}^{-1}\right)$ per tree.

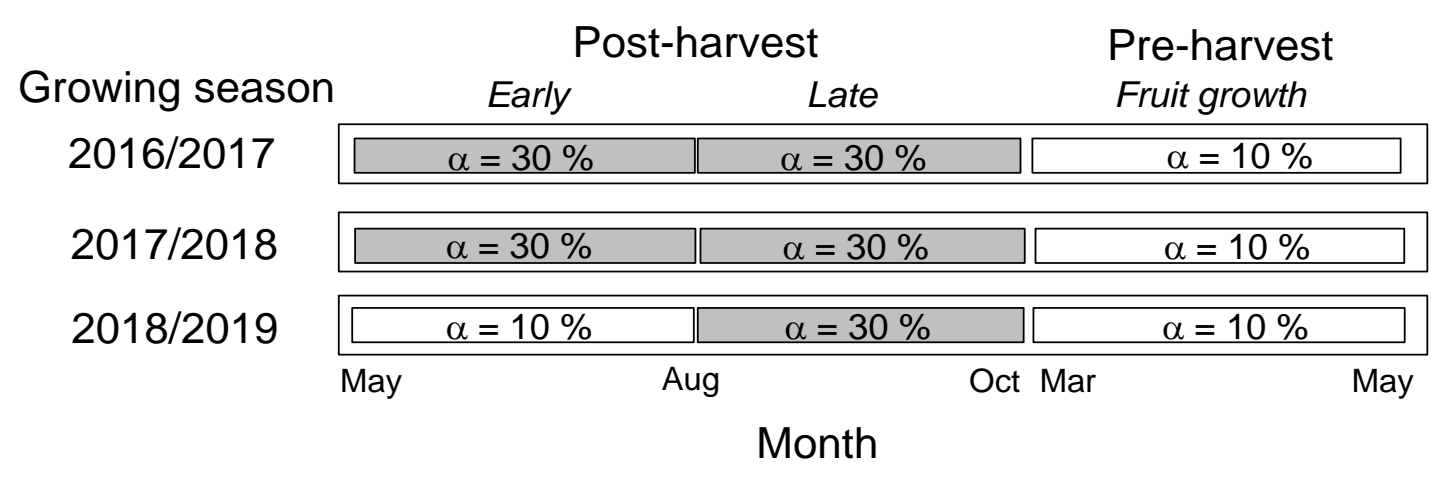


Figure 1. Threshold values of allowed soil water deficit $(\alpha)$ in the T-Auto treatment during the experimental period.

Irrigation was applied daily at night, as needed, except for the T-Auto treatment, in which it was applied anytime when threshold MAD value was reached. The volume of water applied in each irrigation treatment was measured by in-line water meters with digital output pulses (ARAD) located at the beginning of each plot and connected to the telemetry system to detect any flow rate failure.

Treatments were distributed according to a completely randomized blocks design with four replications. Each one consisted of six trees, taking the four central trees for measurements and the remainder served as guard trees, with a total of 24 trees per irrigation scheduling treatment. No active roots were seen more than $1.5 \mathrm{~m}$ from the drip line as revealed root distribution studies (Balsalobre et al., 2018).

\subsection{Soil and plant water status}

Soil water status was estimated by measuring VSWC at 0.1, 0.3, 0.5, and $0.7 \mathrm{~m}$ depth with capacitance probes (EnviroScan ${ }^{\circledR}$, Sentek Pty. Ltd., Adelaide, South Australia). Four PVC access tubes were installed $0.1 \mathrm{~m}$ from the emitter located $0.5 \mathrm{~m}$ from the trunk of four representative trees (one of each replication and treatment). Probes were normalized and calibrated for a clay-loam soil according to Evett et al. (2006) and Abrisqueta et al. (2012). More details can be found in Vera et al. (2019).

Tree water status was estimated by measuring stem water potential ( $\left.\Psi_{\text {stem}}\right)$ using a pressure chamber (Soil Moisture Equip. Crop. Model 3000, Santa Barbara, CA, USA), on mature leaves located on the north face of the tree near the trunk. Leaves were placed in plastic bags covered with aluminum foil for at least $2 \mathrm{~h}$ prior to the measurements, which were carried out at midday every 7 15 days from April to October, each season. One leaf per tree of one tree per replication of each treatment was cut and immediately placed into the chamber following the recommendations of Hsiao (1990). To estimate the intensity of stress the trees of the different irrigation treatments endured during the postharvest period, the water stress integral $\left(S_{\Psi}\right)$ was calculated from the values of

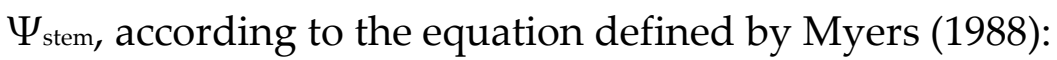

$$
S_{\Psi}=\left|\sum_{i=0}^{i=t}\left(\bar{\Psi}_{i, i+1}-\Psi_{c}\right) n\right|
$$

[Equation 2]

where, $\mathrm{t}$ is the number of measurements of $\Psi_{\text {stem, }} \Psi_{\mathrm{i}, \mathrm{i}+1}$ is the mean $\Psi_{\text {stem }}$ for any measurement $\mathrm{i}$ and $\mathrm{i}+1 ; \Psi_{\mathrm{c}}$ is the maximum $\Psi_{\text {stem }}$ measured during the postharvest period; $\mathrm{n}$ is the number of days in the interval. 


\subsection{Yield and physico-chemical fruit quality}

Nectarine fruits were harvested at commercial maturity on 1-2 picking dates starting at the beginning of May each year. Total yield was weighed in all the experimental trees $(n=24$ trees per treatment) with an electronic scale $(0$ $6000 \pm 2$ g, Scaltec, Model SSH 92, USA). Crop water use efficiency (WUE) was determined as the ratio between total yield and the total amount of irrigation applied at each growing season.

Fruit diameter was measured at harvest on 20 nectarines fruits per replicate $(\mathrm{n}=80$ fruits per treatment) using a digital calliper $(0-150 \pm 0.01 \mathrm{~mm}$; Mitutoyo, CD-15D, Japan).

Fruit quality at harvest $(\mathrm{t}-0)$ was performed in 60 fruits per treatment $(\mathrm{n}=$ 15 nectarines per replicate) and included the following analysis: (i) Firmness, using a texturometer (AGROSTA® 100Field, France) with a piston diameter of $10 \mathrm{~mm}$; (ii) Skin fruit colour parameters, using a photocolorimeter (Konica Minolta Chroma Meter CR-10, Osaka, Japan), expressing the results in the CIEL $a^{*} b^{*}$ chromatic coordinates: $L^{*}$ (lightness), $a^{*}$ (red-green component), $b^{*}$ (blue-yellow component). From these values, chromaticity or Chrome $\left[\mathrm{C}^{*}=\left(a^{* 2}\right.\right.$ $\left.\left.+b^{* 2}\right)^{1 / 2}\right]$ and hue angle $\left[\mathrm{h}^{\circ}=\tan ^{-1}\left(b^{*} / a^{*}\right)\right]$ were determined.

(iii) Total soluble solids (TSS) and titratable acidity (TA), using a digital pocket Brix/Acidity meter (Atago PAL-BX/ACID F5 Master Kit- Multifruits, Japan). Measurements were taken in the juice of five fruits of each replication $(n=20$ fruits per treatment) squeezed with a juice machine (Orbegozo LI-5000, Spain) Values were expressed as ${ }^{\circ}$ Brix and g of malic acid, respectively. The maturity index (MI) was calculated as the soluble solids/acidity ratio.

\subsection{Post-harvest storage study}

A post-harvest storage experiment was carried out during the third growing season (2018/2019) as it was consistent and accurate with data recorded in the previous two growing seasons. At the first pick harvest $\left(2^{\text {nd }}\right.$ May 2019), a sample of about $20 \mathrm{~kg}$ of nectarines per irrigation treatment were taken and immediately transported for $15 \mathrm{~km}$ by car under refrigerated conditions to the storage chamber at CEBAS-CSIC. Fruits with external defects or bruises were eliminated, and sound nectarines were stored at $0-2{ }^{\circ} \mathrm{C}$ air temperature (Ta) and $90-95 \%$ air relative humidity (RH) for 10 days (t-10). After that, a retail shelf-life period at $15{ }^{\circ} \mathrm{C}$ Ta and $70-75 \%$ RH for 5 days was imposed (t-15). Nectarine fruits were sampled at the end of $t-10$ and $t-15$ ( $n=10$ fruits per replication and treatment) for quality analysis.

\subsection{Weight loss and sensory analysis}


Fruit weight loss was determined daily during cold storage and shelf-life periods, relative to the fresh fruit weight obtained at harvest on the same initial 15 nectarines per replicate $(n=60$ nectarines per treatment) used for quality, sensory traits and health-promoting bioactive compounds. A scale (Mettler PE 360 DeltaRange, Switzerland) with an accuracy of $\pm 0.001 \mathrm{~g}$ was used.

Total fruit weight loss (TWL) at the end of cold storage and self-life periods were calculated following the model proposed by Conesa et al. (2014):

$$
\mathrm{TWL}=\sum \text { Time } \times \mathrm{b}
$$

[Equation 3]

where, Time is the number of days in each storage period and $b$ is the slope of the regression line (percent of weight loss per day at each storage period).

Sensory evaluation was performed in five fruits per replicate (20 fruits per treatment) at harvest $(\mathrm{t}-0)$, after cold storage period $(\mathrm{t}-10)$ and at the end of shelf-life period ( $t-15)$, by a panel consisting of trained assessors (4 men and 6 women; aged 25-60) in a room at $20{ }^{\circ} \mathrm{C}$, following a modified protocol of Falagán et al. (2015a). Panellists were trained with the instructions describing the sensory levels of each attribute. Visual appearance, flavour, and overall quality were determined on a five-point hedonic scale representing acceptance: 1 (very poor), 2 (poor), 3 (acceptable, limit of marketability), 4 (good) and 5 (very good), while external colour, off-flavour, dehydration and brown rot (fruit decay) were determined by the following five-point hedonic scale as intensity of disorder: 1 (extreme), 2 (severe), 3 (moderate, limit of marketability), 4 (slight) and 5 (none).

\subsection{Extraction and quantification of individual flavonols and anthocyanin compounds}

Five nectarine fruits ( $\mathrm{n}=20$ fruits per treatment) were sliced, including peel (around 5\% f.w.), in order to obtain whole edible fractions, at harvest $(\mathrm{t}-0)$, and at $\mathrm{t}-10$ and $\mathrm{t}-15$ of the cold storage period. Samples were frozen in liquid $\mathrm{N}_{2}$, ground to a fine powder with a mincer (IKA, A 11 basic, Berlin, Germany), and stored at $-80^{\circ} \mathrm{C}$ until analysed.

For the extraction of phenolic compound, 3 grams of samples were defrosted and homogenized in $10 \mathrm{~mL}$ methanol/MilliQ-water/formic acid (70/29/1; v/v/v). The mixtures were centrifuged at $10500 \mathrm{rpm}$, during $5 \mathrm{~min}$ (Sigma 1-13, B. Braun Biotech International, Osterode, Germany). The supernatants were filtered through a $0.45 \mu \mathrm{m}$ PVDF membrane (Millex HV13, Millipore, Bedford, Mass., USA) and analysed by RP-HPLC-DAD, following the method previously reported by Gironés-Vilaplana et al. (2012), for anthocyanin and flavonol identification and quantification, with some modifications (Agulló et al., 2020). Briefly, samples $(10 \mu \mathrm{L})$ were analysed, using an Agilent Technologies 1220 Infinity Liquid Chromatograph, equipped with an autoinjector (G1313, Agilent Technologies) and a Diode Array Detector (1260, 
Agilent Technologies, California, USA), with a Luna $5 \mu \mathrm{m}$ C18(2)100 $\AA$ column $(250 \times 4.6 \mathrm{~mm})$ and Security Guard Cartridges PFD (4 x $3.0 \mathrm{~mm})$ (Phenomenex, California, USA), using a flow rate of $0.9 \mathrm{~mL} \mathrm{~min}^{-1}$, and a mobile phase of $5 \%$ formic acid in Milli-Q water (v/v) (solvent A) and HPLC grade methanol (Merck, Darmstadt, Germany) (solvent B). Elution was performed using a linear gradient starting with $15 \% \mathrm{~B}$, reaching $30 \% \mathrm{~B}$ at $20 \mathrm{~min}, 40 \%$ at $30,60 \%$ at 35 , $90 \% \mathrm{~B}$ at 40 until $44 \mathrm{~min}$. Finally, gradient came back at $15 \% \mathrm{~B}$ at $45 \mathrm{~min}$ until the end at $50 \mathrm{~min}$. Chromatograms were recorded and processed on an Agilent ChemStation for LC 3D systems (Agilent, California, USA). The quantification of phenolic compounds was done on UV chromatograms recorded at $520 \mathrm{~nm}$ as cyanidin-3-O-glucoside for anthocyanins, and at $360 \mathrm{~nm}$ as Quercetin-3-Oglucoside (Q- 3- O- glc) and Quercetin-3-O-rutinoside (Q- 3- O- rut) for flavonols and expressed as $\mathrm{mg}$ per $100 \mathrm{~g}$ of nectarine.

\subsection{Statistical analysis}

All data were analysed using the SPSS 20 (IBM, Armonk, NY, USA). A two-way analysis of variance (ANOVA) was performed considering separately treatment $(\mathrm{T})$ and season $(\mathrm{S})$, or treatment $(\mathrm{T})$ and time of storage $(\mathrm{t})$ as main effects. Means were compared with the least significant difference test at a confidential level of 95\% (LSD 0.05$)$.

\section{RESULTS}

\subsection{Water applied, soil and plant water status}

The mean irrigation volumes applied during the three-growing season trial amounted 488.2, 502.5 and $276.9 \mathrm{~mm}$ for T-Single, T-Double and T-Auto treatments, respectively (Table 1 ). This fact indicated an average reduction of water applied of $43 \%$ in the T-Auto (based on soil water sensors) respect to the T-Single (based on conventional ETc). This reduction represents a significant saving of $739 €$ for the studied period (2016/2019), according to the rate $\approx 0.35 €$ per $\mathrm{m}^{3}$ (www.chsegura.es). Note that the annual cost of water applied was $1708 €$ in the T-Single, without considering the energy cost.

The volumetric soil water content (VSWC) values remained above field capacity at $0-50 \mathrm{~cm}$ depth in the T-Single treatment, averaging $0.323 \mathrm{~m}^{3} \mathrm{~m}^{-3}$ during the experimental period (Fig. 2A). As expected, VSWC values in the TAuto were significantly lower (by around 17\%) than in the T-Single during the three post-harvest seasons due to the reductions of irrigation applied. Although T-Double, received the same irrigation volume than T-Single, it exhibited lower VSWC values (by around 8\%), which promoted slight soil water deficit (Fig. 2A). No significant differences were detected in the VSWC values among treatments during the pre-harvest seasons. 
Table 1. Seasonal rainfall $(\mathrm{mm})$, reference crop evapotranspiration $\left(\mathrm{ET}_{0}, \mathrm{~mm}\right)$ and irrigation water applied (mm) in the three irrigation treatments during the three growing seasons (from May to May) of the experimental period (2016/2017-2018/2019).

\begin{tabular}{|c|c|c|c|c|c|c|c|c|c|c|c|}
\hline \multirow{3}{*}{$\begin{array}{l}\text { Growing } \\
\text { season }\end{array}$} & \multirow{3}{*}{$\begin{array}{l}\text { Seasonal } \\
\text { rainfall }\end{array}$} & \multirow{3}{*}{$\begin{array}{l}\text { Seasonal } \\
\mathrm{ET}_{0}\end{array}$} & \multicolumn{9}{|c|}{ Irrigation ( } \\
\hline & & & \multicolumn{3}{|c|}{ T-Single } & \multicolumn{3}{|c|}{ T-Double } & \multicolumn{3}{|c|}{ T-Auto } \\
\hline & & & Post ${ }^{\mathrm{a}}$ & Pre $^{b}$ & Total & Post & Pre & Total & Post & Pre & Totalc \\
\hline $2016 / 2017$ & 443 & 1141 & 572.0 & 23.7 & 595.7 & 604.3 & 34.2 & 638.5 & 240.7 & 38.8 & $279.6(53)$ \\
\hline $2017 / 2018$ & 195 & 1094 & 359.5 & 39.6 & 399.1 & 380.1 & 39.8 & 419.9 & 202.1 & 45.8 & $247.9(38)$ \\
\hline $2018 / 2019$ & 392 & 1081 & 427.3 & 42.6 & 470.0 & 407.2 & 42.0 & 449.2 & 279.2 & 24.0 & $303.2(35)$ \\
\hline Average & 342 & 1105.3 & 452.9 & 35.3 & 488.2 & 463.9 & 38.7 & 502.5 & 240.7 & 46.2 & $276.9(43)$ \\
\hline
\end{tabular}

aPost $=$ Post-harvest period (May to October of the year before harvest)

bPre $=$ Pre-harvest period (March to May of the current year's harvest)

c(percentage with respect to the T-Single treatment) 


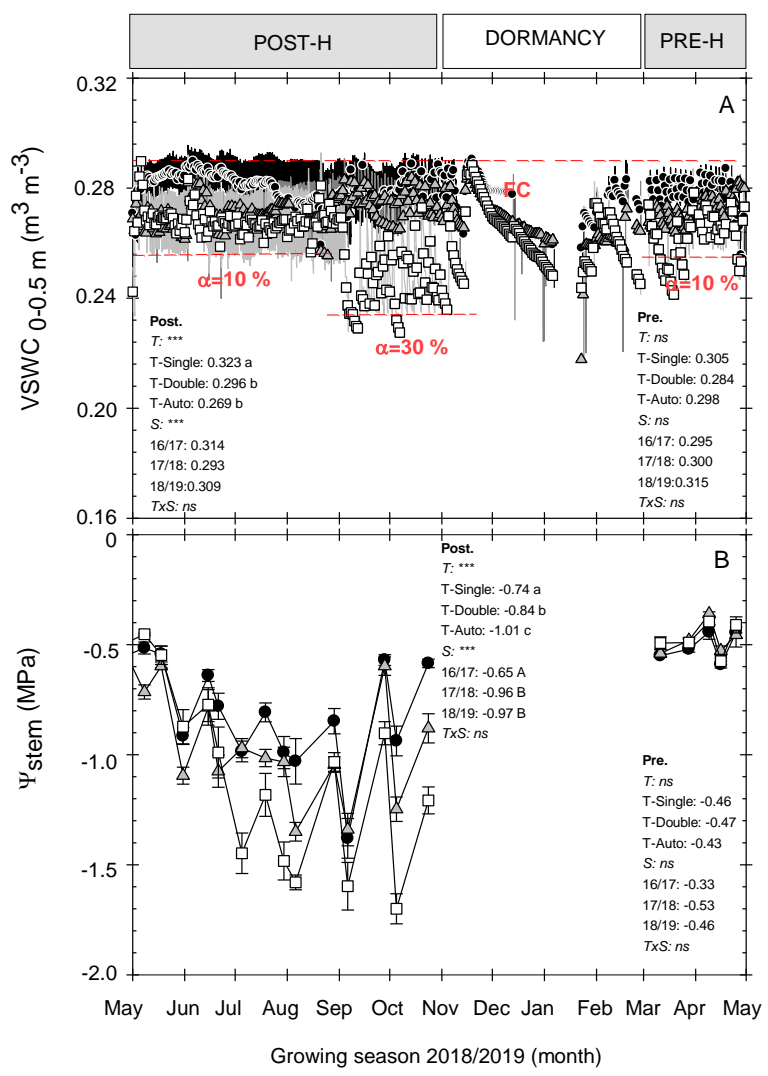

Figure 2. Seasonal evolution of (A) volumetric soil water content (VSWC) at the 0-0.5 m layer of the soil profile as $15 \mathrm{~m}$ recorded values (lines) and computed daily means (symbols), and (B) midday stem water potential ( $\left.\Psi_{\text {stem }}\right)$ in nectarine trees in the different irrigation treatments: T-Single (back, • ), T-Double (dark grey, $\Delta$ ) and T-Auto (grey, $\square$ ) during the 2018/2019 growing season. Values are mean \pm SE $(n=4)$. Dashed horizontal red lines delimit field capacity (FC) and the allowed plant water deficit $(\alpha)$ threshold values (as indicated in Fig. 1). Phenological periods for nectarine trees are depicted in the top box. ANOVA for the whole experimental period (2016/2017-2018/2019) is indicated for the post-harvest and pre-harvest periods: Treatment $(\mathrm{T})$, Season $(\mathrm{S})$ and $\mathrm{T} \times \mathrm{S}$ interaction, ns: not significant, ${ }^{* * *} p \leq 0.001$. Means followed by different lowercase letters indicate significant differences between treatments, while capital letters indicate significant differences between seasons according to LSD $_{0.05}$ test. 
Tree water status, as assessed by $\Psi_{\text {stem values, ranged between }-0.34 \text { and }}$ $-0.58 \mathrm{MPa}$, and -0.57 to $-0.84 \mathrm{MPa}$ during the pre-harvest and post-harvest periods, respectively in the T-Single, which was in agreement with the high VSWC values (around field capacity) observed in this treatment and with the increasing environmental conditions during summer (Table 1 and Fig. 2). During the three pre-harvest seasons, the mean values of $\Psi_{\text {stem }}$ in the T-Auto and T-Double were similar to those of the T-Single (Fig. 2B). On average $\Psi_{\text {stem }}$ decreased by around $0.27 \mathrm{MPa}$ in the post-harvest period in the T-Auto trees compared to T-Single trees, with a maximum difference of $0.31 \mathrm{MPa}$ in the 2018/2019 growing season.

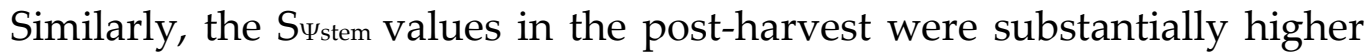
in trees from the T-Auto $(\approx 43 \%$ with respect to the T-Single) due to the reduction in the water applied (Table 1). Both, $\Psi_{\text {stem }}$ and $S \Psi_{\text {stem }}$ values were indicative of a moderate water deficit situation (Fig. 2 B and Fig. 3). Meanwhile, the reduction in VSWC in the T-Double promoted a mild tree water deficit, with a reduction of $0.10 \mathrm{MPa}$ in $\Psi_{\text {stem }}$ and an increase of $13 \%$ in $S_{\Psi_{s t e m}}$ during the postharvest period as compared with the T-Single (Fig. 2 B and Fig. 3).

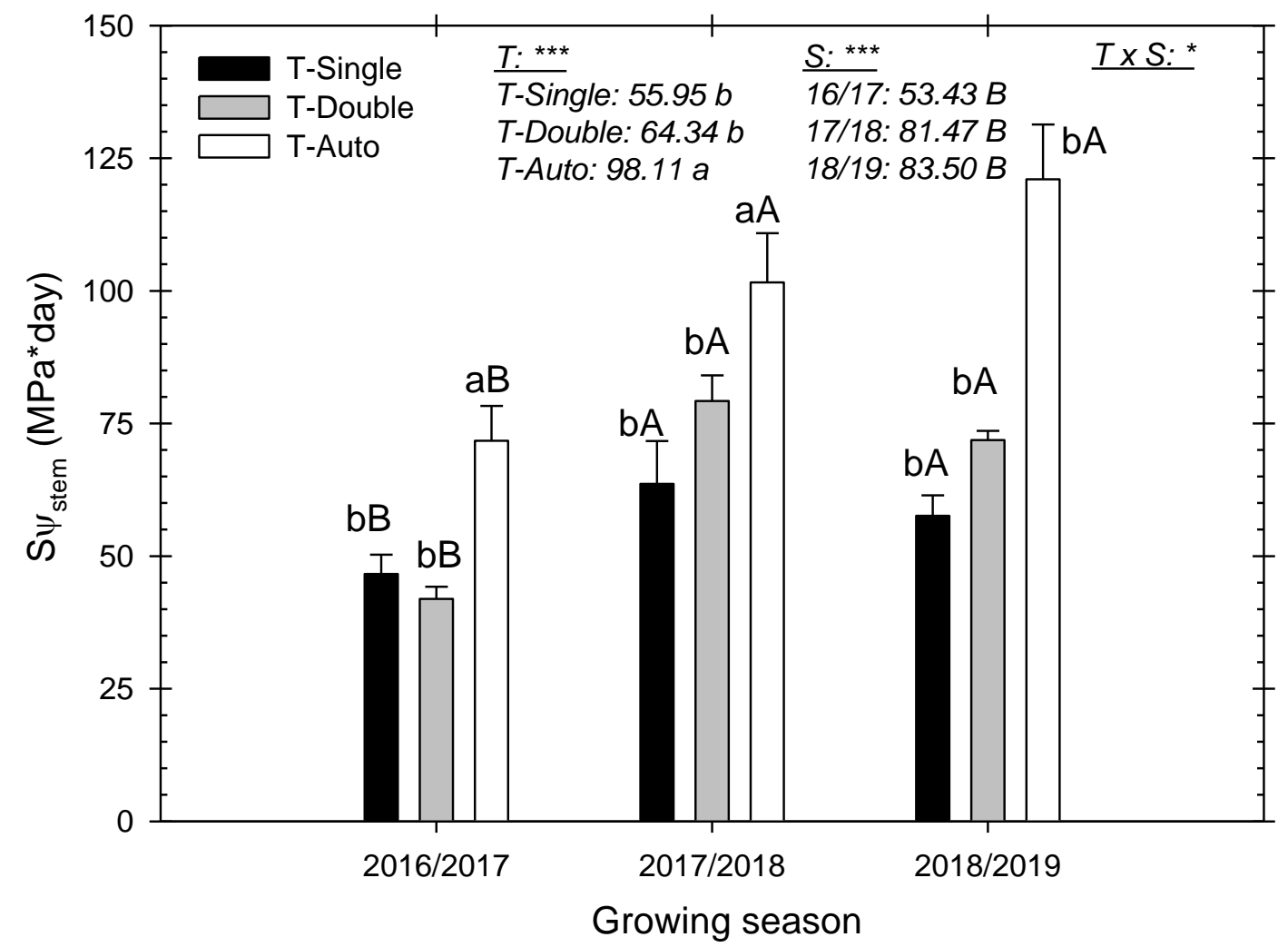

Figure 2. Post-harvest water stress integral ( $S_{\left.\Psi_{s t e m}\right)}$ in nectarine trees in the different irrigation treatments during the experimental period (2016/2017-2019). Bars on each column are mean \pm SE $(n=4)$. ANOVA: Treatment $(T)$, Season $(S)$ 
and $\mathrm{T} \times \mathrm{S}$ interaction, ns: not significant, ${ }^{*}: p \leq 0.05,{ }^{* *}: p \leq 0.001$. Means followed by different lowercase letters indicate significant differences between treatments, while capital letters indicate significant differences between seasons according to LSD 0.05 test.

\subsection{Yield, fruit diameter and WUE}

Total yield and fruit diameter at harvest were similar in all the irrigation management treatments (Table 2). It is important to notice that yield refers only to nectarine fruits with adequate commercial quality traits (i.e. fruits affected by cracking were eliminated). Interestingly, no significant differences in fruit cracking were detected among the irrigation treatments during the experimental period (2016/2017-2018/2019), with average values $\approx 38 \%$ of the total fruit yield (data not shown). The two-way analysis of variance indicated the inter-annual significant effect on yield, which was likely related to differences in crop management practices, mainly fruit thinning. In all treatments and growing seasons, the mean fruit cheek to cheek diameter corresponded to ' $\mathrm{B}^{\prime}$ ' category (61-67 mm) according to EEC directive 3596/90 (EC № 1221, 2008).

Generally, T-Auto resulted in higher WUE values compared to the other irrigation treatments (Fig. 3). Even though this effect was minimized in the last growing season (2018/2019), WUE showed more dependence on the treatment (T) than the season (S) effect (Fig. 3). 
Table 2. Total nectarine yield $\left(\mathrm{t} \mathrm{ha}^{-1}\right)$ and fruit diameter $(\mathrm{mm})$ at harvest in the different irrigation treatments during the experimental period (2016-2019).

\begin{tabular}{lcc}
\hline Growing season / Treatment & Yield & Fruit diameter \\
\hline 2016/2017 & 15.59 & 65.35 \\
T-Single & 13.96 & 64.09 \\
T-Double & 12.99 & 65.34 \\
T-Auto & & \\
2017/2018 & 8.37 & 64.62 \\
T-Single & 6.10 & 62.13 \\
T-Double & 6.25 & 66.38 \\
T-Auto & & \\
2018/2019 & 10.43 & 65.49 \\
T-Single & 11.13 & 63.42 \\
T-Double & 10.01 & 66.54 \\
T-Auto & & $\mathrm{ns}$ \\
\hline ANOVA/ Means & $\mathrm{ns}$ & 65.15 \\
\hline Treatment $(T)$ & 11.46 & 63.21 \\
T-Single & 10.39 & 66.08 \\
T-Double & 9.75 & $\mathrm{~ns}$ \\
T-Auto & $* * *$ & 64.93 \\
Season (S) & $14.18 \mathrm{~A}$ & 64.38 \\
2016/2017 & $6.90 \mathrm{C}$ & 65.15 \\
2017/2018 & $10.52 \mathrm{~B}$ & $\mathrm{~ns}$ \\
2018/2019 & $\mathrm{ns}$ & \\
T $x$ S & & \\
\hline AN & & \\
\hline
\end{tabular}

ANOVA: Treatment (T), Season (S), and $\mathrm{T} \times \mathrm{S}$ interaction, ns: not significant, ${ }^{* *}$ : $p \leq 0.001$. Means followed by different capital letters indicate significant differences between seasons according to LSD 0.05 test. 


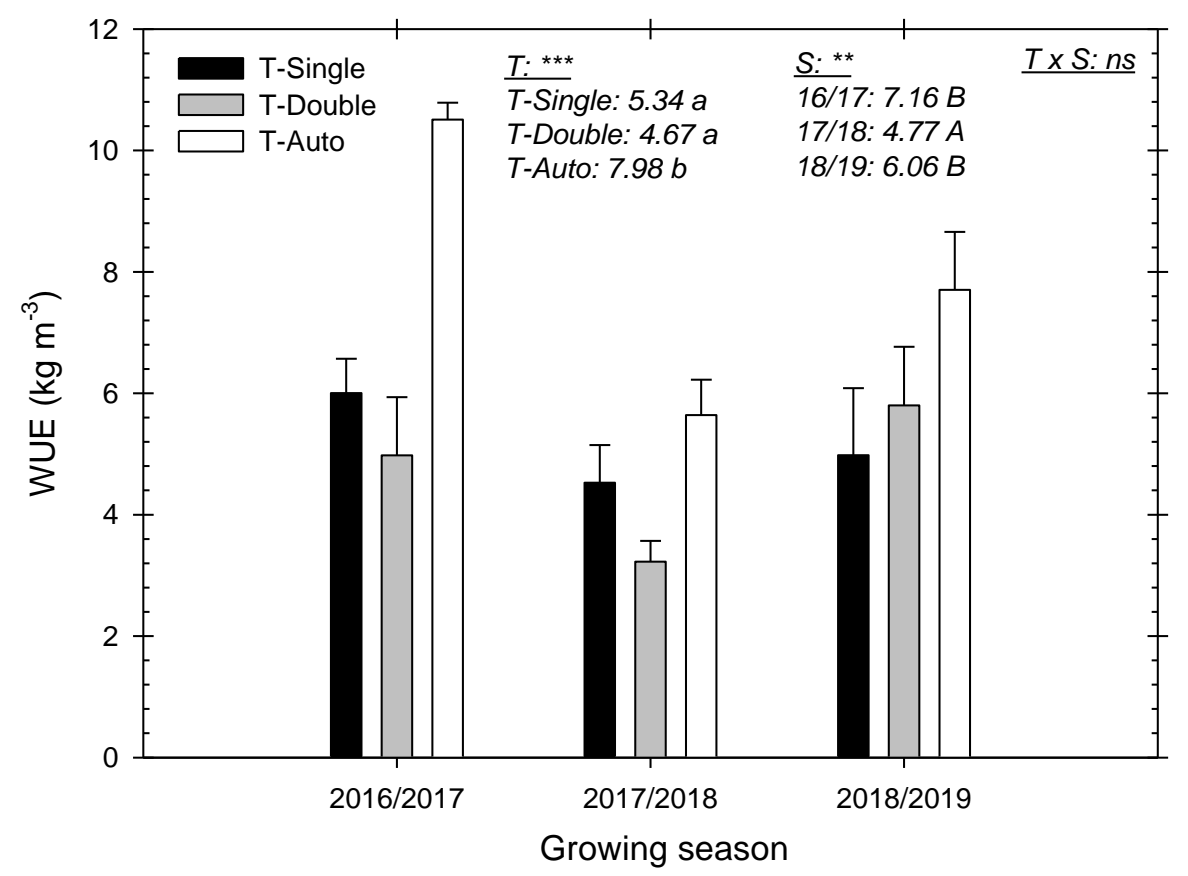

Figure 3. Crop water use efficiency (WUE) in nectarine trees in the different irrigation treatments during the experimental period (2016-2019). Bars on each column are mean \pm SE $(\mathrm{n}=4)$. ANOVA: Treatment $(\mathrm{T})$, Season $(\mathrm{S})$ and $\mathrm{T} \times \mathrm{S}$ interaction, ns: not significant, ${ }^{* *}: p \leq 0.01,{ }^{* *}: p \leq 0.001$. Means followed by different lowercase letters indicate significant differences between treatments, while capital letters indicate significant differences between seasons according to LSD 0.05 test.

\subsection{Fruit quality at harvest and during storage period}

No significant differences were observed between irrigation treatments in the fruit colour parameters evaluated at harvest (Table 3).

Regarding the physico-chemical quality traits of nectarine fruits at harvest, only TSS values showed significant differences among irrigation treatments (Table 3), with highest values in fruits from the T-Auto (10.72 ${ }^{\circ}$ Brix), as compared to T-Single $\left(9.57^{\circ}\right.$ Brix) and T-Double (9.82 ${ }^{\circ}$ Brix). TA and MI were not significant among irrigation treatments (Table 3 ).

Regarding flavonoids composition, the main anthocyanin was Cyanidin 3-glucoside, which concentration was significantly higher, at harvest, in the TSingle (4.84 mg per $100 \mathrm{~g}$ f.w.) followed by T-Auto (4.27 mg per $100 \mathrm{~g}$ f.w.) and T-Double (4.24 mg per $100 \mathrm{~g}$ f.w.) (Table 3). On the other hand, the noncoloured flavonoids showed significantly higher levels of Q- 3- O- rut in TSingle (2.82 mg per $100 \mathrm{~g}$ f.w.) vs. T-Double (2.62 mg per $100 \mathrm{~g}$ f.w.) and T-Auto (2.59 mg per $100 \mathrm{~g}$ f.w.), being the most abundant flavonol in the nectarine fruits tested. ). Meanwhile, Q- 3- O- glc concentration was similar among irrigation treatments (Table 3 ). 
Table 3. Physico-chemical traits, anthocyanins and non-coloured flavonols contents of nectarine fruits at harvest ( $\mathrm{t}-0)$, end of cold storage $\left(10\right.$ days at $\left.0{ }^{\circ} \mathrm{C}, \mathrm{t}-10\right)$, and end of shelf- life $\left(5\right.$ days at $\left.15{ }^{\circ} \mathrm{C}, \mathrm{t}-15\right)$ in the different irrigation treatments.

\begin{tabular}{|c|c|c|c|c|c|c|c|c|c|c|}
\hline Period & Firmness & $\mathrm{L}$ & $\mathrm{H}^{*}$ & $C^{*}$ & TSS & TA & IM & Cy-3-glc & Q 3-O- rut & Q 3-O-glc \\
\hline \multicolumn{11}{|l|}{ Harvest } \\
\hline T-Single & 89.25 & 38.38 & 38.77 & 27.97 & 9.57 & 13.42 & 7.77 & $4.84 \mathrm{aA}$ & $2.82 \mathrm{aA}$ & $2.00 \mathrm{~A}$ \\
\hline T-Double & 86.52 & 39.70 & 39.59 & 29.73 & 9.82 & 14.62 & 7.58 & $4.24 \mathrm{bA}$ & $2.62 \mathrm{bB}$ & $2.04 \mathrm{~B}$ \\
\hline T-Auto & 86.75 & 38.52 & 38.49 & 28.09 & 10.72 & 10.65 & 10.17 & $4.27 \mathrm{bA}$ & $2.59 \mathrm{bB}$ & $2.00 \mathrm{~B}$ \\
\hline \multicolumn{11}{|l|}{ Cold storage $(t-0)$} \\
\hline T-Single & 88.77 & 37.11 & 37.90 & 29.18 & 9.80 & 10.12 & 9.70 & $3.28 \mathrm{aB}$ & $2.64 \mathrm{cB}$ & $2.07 \mathrm{cA}$ \\
\hline T-Double & 89.27 & 38.94 & 38.52 & 31.26 & 9.65 & 9.72 & 9.92 & $2.92 \mathrm{bB}$ & $2.95 \mathrm{aA}$ & $2.39 \mathrm{aA}$ \\
\hline T-Auto & 89.42 & 38.03 & 38.24 & 29.29 & 10.62 & 9.97 & 10.64 & $2.22 \mathrm{cB}$ & $2.71 \mathrm{bA}$ & $2.20 \mathrm{bA}$ \\
\hline \multicolumn{11}{|l|}{ Shelf-life ( $t-15)$} \\
\hline T-Single & 49.45 & 38.15 & 36.49 & 31.56 & 10.07 & 14.77 & 7.04 & $1.73 \mathrm{aC}$ & $2.17 \mathrm{aC}$ & $1.79 \mathrm{aB}$ \\
\hline T-Double & 49.60 & 40.48 & 37.67 & 34.11 & 10.07 & 16.40 & 6.20 & $1.20 \mathrm{bC}$ & $2.00 \mathrm{bC}$ & $1.62 \mathrm{bC}$ \\
\hline T-Auto & 48.25 & 39.04 & 36.21 & 32.46 & 10.25 & 11.32 & 9.67 & $1.07 \mathrm{bC}$ & $1.92 \mathrm{bC}$ & $1.56 \mathrm{bC}$ \\
\hline \multicolumn{11}{|l|}{ ANOVA/Means } \\
\hline Treatment (T) & ns & ** & ns & ns & * & ns & * & $* * *$ & $* * *$ & $* * *$ \\
\hline T-Single & 75.60 & $37.88 \mathrm{~b}$ & 37.72 & 29.57 & $9.86 \mathrm{~b}$ & 12.92 & $8.20 \mathrm{~b}$ & $3.26 \mathrm{a}$ & $2.54 \mathrm{a}$ & $1.95 \mathrm{~b}$ \\
\hline T-Double & 74.72 & $39.71 \mathrm{a}$ & 38.59 & 31.70 & $9.85 \mathrm{~b}$ & 13.63 & $7.97 \mathrm{~b}$ & $2.76 \mathrm{~b}$ & $2.52 \mathrm{a}$ & $2.01 \mathrm{a}$ \\
\hline T-Auto & 75.23 & $38.53 \mathrm{~b}$ & 37.65 & 29.95 & $10.53 \mathrm{a}$ & 10.60 & $10.22 \mathrm{a}$ & $2.52 \mathrm{c}$ & $2.40 \mathrm{~b}$ & $1.92 \mathrm{~b}$ \\
\hline Time of storage $(t)$ & $* * *$ & ns & $* *$ & $* * *$ & ns & * & * & $* * *$ & $* * *$ & $* * *$ \\
\hline $\mathrm{t}-0$ & $87.30 \mathrm{~B}$ & 38.86 & $38.95 \mathrm{~A}$ & $28.60 \mathrm{~B}$ & 10.10 & $13.04 \mathrm{~A}$ & $8.67 \mathrm{~A}$ & $4.43 \mathrm{~A}$ & $2.66 \mathrm{~B}$ & $2.01 \mathrm{~B}$ \\
\hline $\mathrm{t}-10$ & $89.15 \mathrm{~A}$ & 38.03 & $38.22 \mathrm{~A}$ & $29.91 \mathrm{~B}$ & 10.09 & $9.94 \mathrm{~B}$ & $10.09 \mathrm{~A}$ & $2.80 \mathrm{~B}$ & $2.76 \mathrm{~A}$ & $2.21 \mathrm{~A}$ \\
\hline $\mathrm{t}-15$ & $49.11 \mathrm{C}$ & 39.22 & $36.79 \mathrm{~B}$ & $32.71 \mathrm{~A}$ & 10.13 & $14.16 \mathrm{~A}$ & $7.63 \mathrm{~B}$ & $1.32 \mathrm{C}$ & $2.02 \mathrm{C}$ & $1.66 \mathrm{C}$ \\
\hline$T x t$ & ns & ns & ns & ns & ns & ns & ns & $* * *$ & $* * *$ & $* * *$ \\
\hline
\end{tabular}


$L^{*}$ : lightness; $h^{\circ}$ : hue angle; $\mathrm{C}^{*}$ : chrome; Firmness (\%); total soluble solid content (TSS, ${ }^{\circ}$ Brix); titratable acidity (TA, mg malic acid L$\left.{ }^{1}\right)$ )) maturity index (MI); Anthocyanins: cyanidin 3- glucoside (mg per $100 \mathrm{~g} \mathrm{f.w.)} \mathrm{and} \mathrm{Non-coloured} \mathrm{flavonoids:} \mathrm{Quercetin} \mathrm{3-O-}$ rutinoside (mg per $100 \mathrm{~g}$ f.w.) and Quercetin 3-O-glucoside (mg per $100 \mathrm{~g}$ f.w.) Values are mean of 10 fruits per replicate (n= 40 fruits per treatment) for physico-chemical and five fruits per replicate ( $\mathrm{n}=20$ fruits per treatment) for anthocyanins and flavonols content. ANOVA: Treatment $(\mathrm{T})$, time of storage $(\mathrm{t})$ and $\mathrm{T} \times \mathrm{t}$ interaction, ns: not significant, ${ }^{*}: p \leq 0.05 ;{ }^{* *}: p \leq 0.01 ;{ }^{* *}: p \leq 0.001$. Means followed by different lowercase letters indicate significant differences between treatments, while capital letters indicate significant differences between times of storage according to LSD 0.05 test. 
Most of the fruit colour traits studied were affected by the time of storage $(t)$, being independent of the irrigation treatment, which were slightly affected by irrigation treatment at the end of the shelf-life period (Table 3). An increase in $\mathrm{C}^{*}$ were noted during storage period, whereas $\mathrm{h}^{\circ}$ decreased slightly in nectarine fruits, especially at the end of the self-life period.

The anthocyanins content fell sharply after harvest and were significantly affected $(p<0.001)$ by irrigation treatment $(\mathrm{T})$ and time of storage $(\mathrm{t})$, being also statistically significant the $\mathrm{T} \times \mathrm{t}$ interaction, with nectarine fruits from T-Single showing the highest values during all storage period (Table 3). Total quercetin content was higher in nectarine fruits from T-Double than in the other treatments at the end of the cold storage period, with mean values of 2.95 $\mathrm{mg}$ per $100 \mathrm{~g}$ f.w. (Q- 3- O- rut) vs. 2.71 and 2.64 in T-Auto and T-Single, respectively (Fig. 4A), and $2.39 \mathrm{mg}$ per $100 \mathrm{~g}$ f.w. (Q- 3- O- glc) vs. 2.20 and 2.07 in T-Auto and T-Single, respectively (Table 3). Interestingly, the time of storage (t) considerably influenced the amount of both individual compounds, even if differently for each treatment, as indicated the significance of the interaction $\mathrm{T} x$ t. The increase in temperature to $15{ }^{\circ} \mathrm{C}$ at the end of the retail sale period drastically reduced both individual non-coloured flavonoids content in all the studied treatments, except for Q- 3- O-glc in the fruits from the T-Single, which maintained the highest levels (Table 3).

Fruit firmness remained constant after 10 days at $0{ }^{\circ} \mathrm{C}$ and decreased, as expected, at the end of the shelf-life period irrespectively of the treatment considered (Table 3). Among chemical parameters, only TSS and IM were significantly affected by treatment effect during storage. However, apart from TSS, that was constant throughout the storage experiment, all chemical parameters changed with time of storage. TA decreased after 10 days cold storage and then it increased with the increase in temperature at the end of selflife. (This caused the opposite changes in the maturity index (Table 3).

There were noticeable differences among treatments in weight loss values during cold storage and shelf-life periods, as indicated the model proposed in Table 4. It was clear that the slope of the regression line increased at the end of the retail shelf-life period, as weight loss increased in the three treatments following this order: T-Single $>$ T-Double $>$ T-Auto. Therefore, nectarine fruits from T-Auto showed the lowest value of TWL $(5.80 \%)$ at the end of the storage period (cold + self-life) compared to the other irrigation treatments.

Sensory evaluation is shown in Figure 4. No off-odors or wilting were detected in any treatment after cold storage or subsequent shelf-life period (data not shown). T-Single showed the worst score for fruit dehydration (softness) and fruit decayed at the end of the retail sale period, coinciding with the highest weight loss values (Table 4). The typical fungi that appear during 
cold storage might be Monilinia fructigena (Zhu et al., 2005) which caused browning, and only a few fruits in the T-Single showed Botrytis sp. (Fig. 4E). Indeed, browning was the most important factor that affected the visual appearance and external fruit colour appreciation. Nectarines fruits from the TAuto registered better scores for visual appearance, external fruit colour, fruit dehydration and fruit decayed than the other irrigation treatments (Fig. 4.A, B, $\mathrm{D}$ and E). Therefore, although the overall sensory quality showed that nectarines were suitable for consumption in all treatments, nectarines from the T-Auto were the best classified by consumers.

Table 4. Regression analysis between daily weight loss and time during cold storage $\left(10 \mathrm{~d}\right.$ at $\left.0{ }^{\circ} \mathrm{C}\right)$, and shelf-life $\left(5 \mathrm{~d}\right.$ at $\left.25^{\circ} \mathrm{C}\right)$, and total weight loss (TWL) during the complete storage $\left(10 \mathrm{~d}\right.$ at $5{ }^{\circ} \mathrm{C}+5 \mathrm{~d}$ at $\left.25^{\circ} \mathrm{C}\right)$ in the different irrigation treatments.

\begin{tabular}{|c|c|c|c|c|c|c|c|c|c|c|c|c|}
\hline \multirow[b]{2}{*}{ Time } & \multicolumn{4}{|c|}{ T-Single } & \multicolumn{4}{|c|}{ T-Double } & \multicolumn{4}{|c|}{ T-Auto } \\
\hline & \multicolumn{12}{|c|}{$y=a+b \times W L$} \\
\hline & $\mathrm{a}$ & $\mathrm{b}$ & $\mathrm{r}^{2}$ & $p$ & $\mathrm{a}$ & $b$ & $\mathrm{r}^{2}$ & $p$ & $\mathrm{a}$ & $b$ & $\mathrm{r}^{2}$ & $p$ \\
\hline Cold storage & 0.367 & 0.307 & 0.96 & $* * *$ & 0.246 & 0.292 & 0.98 & $* * *$ & 0.351 & 0.335 & 0.94 & $* * *$ \\
\hline \multirow[t]{2}{*}{ Shelf-life } & -3.46 & 0.682 & 0.93 & * & -3.29 & 0.662 & 0.90 & * & -0.95 & 0.491 & 0.93 & $*$ \\
\hline & \multicolumn{12}{|c|}{$W L=$ Time $x b$} \\
\hline Cold storage & \multicolumn{4}{|c|}{3.07} & \multicolumn{4}{|c|}{2.92} & \multicolumn{4}{|c|}{3.35} \\
\hline Shelf-life & \multicolumn{4}{|c|}{3.41} & \multicolumn{4}{|c|}{3.31} & \multicolumn{4}{|c|}{2.45} \\
\hline TWL & \multicolumn{4}{|c|}{6.48} & \multicolumn{4}{|c|}{6.23} & \multicolumn{4}{|c|}{5.80} \\
\hline
\end{tabular}

WL: Percentage of weight loss in each storage period; Time: days of each storage period; $b$ : the slope of the regression line (weight loss per day). $r^{2}$ : coefficient of determination. $p$ : $p$-value of regression line. ${ }^{*}: p \leq 0.05,{ }^{* * *}: p \leq 0.001$. 

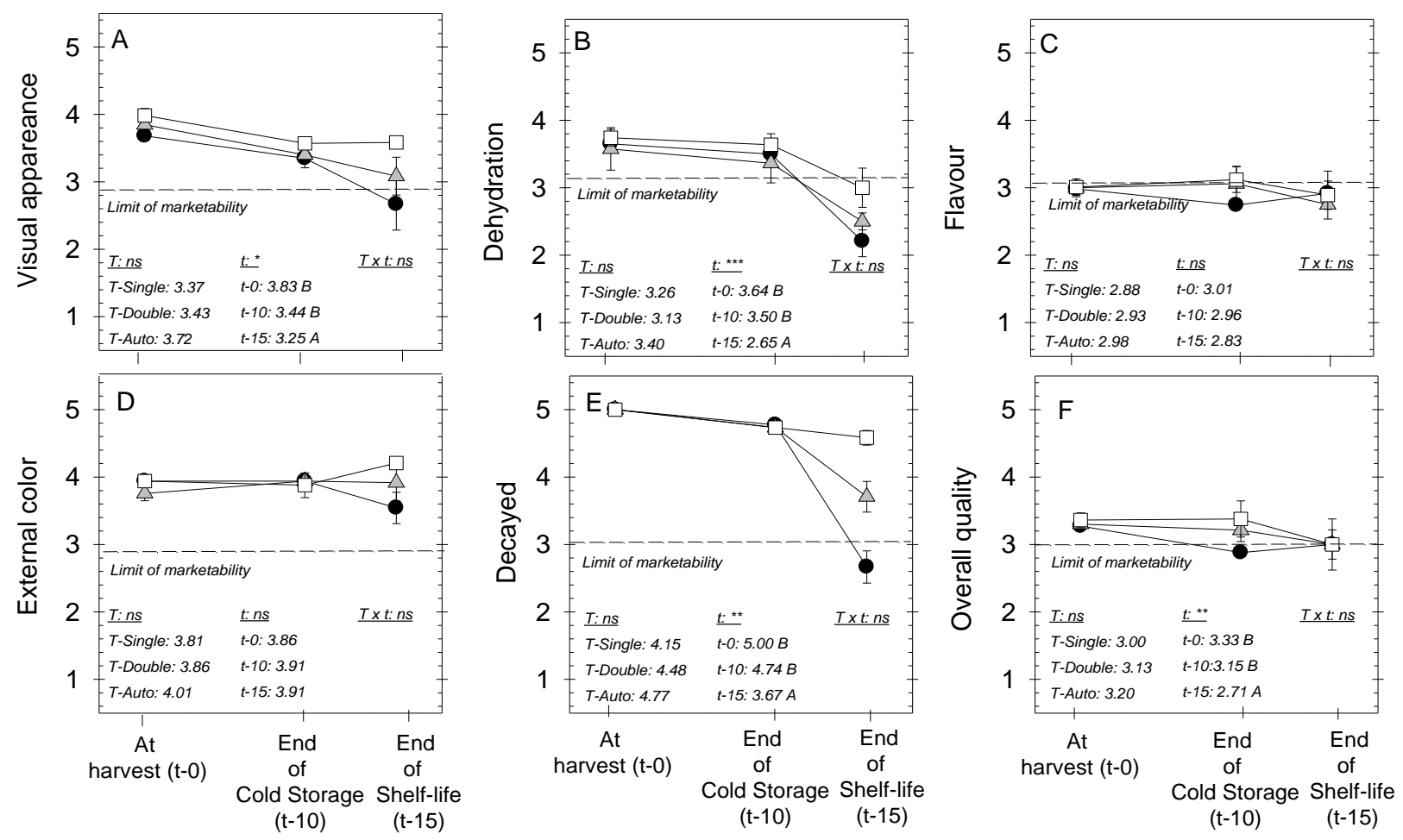

Time of storage (days)

Figure 4. Sensory score for (A) visual appearance, (B) fruit dehydration, (C) flavour (D) external colour, (E), fruit decayed and (F) overall quality of nectarine fruits in the different irrigation treatments: T-Single $(\bullet)$, T-Double ( $\Delta$ ) and T-Auto ( $\square$ ), at harvest (t-0), at the end of cold storage (10 days at $0{ }^{\circ} \mathrm{C}$, $\mathrm{t}-10)$, and at the end of shelf-life period ( 5 days at $\left.25^{\circ} \mathrm{C}, \mathrm{t}-15\right)$. Values are means \pm SE of five fruits per replicate $(\mathrm{n}=20$ fruits per treatment). ANOVA: Treatment $(\mathrm{T})$, time of storage $(\mathrm{t})$, and $\mathrm{T} \times \mathrm{t}$ interaction, ns: not significant, ${ }^{*}: p \leq 0.05,{ }^{* *}: p \leq$ $0.01,{ }^{* *}: p \leq 0.001$. Different lowercase letters indicate significant differences between treatments, while capital letters indicate significant differences between times of storage, according to LSD 0.05 test.

\section{DISCUSSION}

\subsection{Water status and yield}

Field-grown early-maturing nectarine trees suffered from water deficit during the postharvest via different irrigation management practices. In one hand, the irrigation management based on real-time soil water content values (T-Auto) and on the other hand the irrigation management design using twoline of emitters (T-Double). We will analyse the causes of this water deficit and the main effects on fruit yield separately for each irrigation treatment, compared to the T-Single treatment. 
In the T-Auto irrigation the SWC criteria was deliberately lowered during the late post-harvest, a non-critical period for water deficit when nectarine trees are less sensitive to water stress (de la Rosa et al., 2015; RuizSánchez et al., 2018). This caused a 17\% reduction in the VSWC values during the post-harvest, as compared with the T-Single (Fig 1A), which promoted a moderate plant water deficit, as indicated the $0.27 \mathrm{MPa}$ lower $\Psi_{\text {stem values and }}$ $43 \mathrm{MPa}$ * day higher S$\Psi_{\text {stem, }}$ with respect to the T-Single trees (Figs. 1B and 2) These reductions in the plant water status indicators revealed a moderate water stress situation under drip irrigation conditions (Ruiz-Sánchez et al., 2010; Pérez-Pastor et al., 2016).

However, the midday stem water potential $\Psi_{\text {stem, long-established as the }}$ best reference plant water status for early maturing nectarine trees (Conesa et al. (2019b), did not reach threshold values as those indicated to ensure no impairment of bloom fertility (-1.5 MPa) (Girona et al., 2005), $-2.0 \mathrm{MPa}$ to limit the occurrence of T-Double fruits for peach trees (Naor et al., 2005), or -1.80 $\mathrm{MPa}$ to become detrimental of pear fruit quality (Lopez et al., 2011). Furthermore, a short-mild water deficit ( $\Psi_{\text {stem }}=-1.25 \mathrm{MPa}$ ) before harvest might negatively affect mid-maturing nectarine fruit size and yield (López et al., 2016). This is why these negative features were translate into important water saving, allowing trees from the T-Auto treatment to receive $43 \%$ less irrigation water than those from T-Single, without compromising total yield (Tables 1 and 2) and maintaining similar physico-chemical quality of nectarine fruits at harvest and after cold storage plus the subsequent shelf-life periods (Table 3). It is worth nothing the $34 \%$ increase in the water use efficiency (WUE) values with respect to T-Single (Fig. 3).

It is important to note that all treatments showed similar $\Psi_{\text {stem values }}$ during the three pre-harvest growing seasons (Fig. 1B), with the characteristic high values of well-irrigated trees (Girona and Fereres 2012; de la Rosa et al., 2015; Falagán et al., 2015a; Conesa et al., 2019; Vera et al., 2019).

The absence of differences between the irrigation management conditions studied as regards to fruit yield (Table2), coincides with previous research on automatically managed irrigation by monitoring the soil water content in Prunus trees (Vera et al., 2013; Conesa et al., 2019b). Similarly, an automated system based on soil moisture sensors, reported by Millan et al. (2019), was able to establish an RDI strategy without affecting plum fruit production and tree vigour with respect to conventional RDI based on $40 \%$ ETc. Dominguez-Niño et al. (2020) stated that any negative effects were observed on yield of one automated management treatment, which were irrigated at similar amount as the classical water balance method, or in smaller trees, where the automated algorithm saved $23 \%$ of irrigation water.

Meanwhile, implementing two-line of emitters (T-Double) triggered a mild soil-plant water deficit, despite of receiving the same amount of irrigation 
than the one-line of emitters (T-Single), both of them with the irrigation scheduling based on $100 \%$ of ETc (Table 1). The slight soil water deficit (Fig. 1A) decreased $\Psi_{\text {stem }}$ in $0.10 \mathrm{MPa}$ and increased the water stress integral by $13 \%$ in this treatment (Fig. 1B and Fig. 2).

The T-Double received the same amount of water as in the T-Single (Table 1) but divided into two lines. Since water is incompressible, it was clear that the increased number of emitters resulted in wider wet bulbs, even though the heterogeneous pattern of soil moisture (Samadianfard et al., 2012), spreading in the horizontal direction (Ondrasek et al., 2008) and limited in depth (Balsalobre et al., 2018). As a result of the T-Double wetted surface, less water would be loss in depth and trees should improve the water uptake. However, a mild-plant water deficit was observed in T-Double during the postharvest period (Fig. 1B and Fig. 2). The higher electrical conductivity of the top layer, reported in drip irrigated conditions (Million et al., 2007), as a result of evaporation of water from the soil surface between irrigation events, may be significant (Guttormsen, 1969). Therefore, the mild water deficit observed in TDouble can be attributed to a higher salt accumulation on the top-soil layers, but insufficient to adversely affect yield and fruit quality parameters.

\subsection{Fruit quality at harvest and after storage}

Automated irrigation was seen to increase the TSS levels of nectarine fruits at harvest (Table 3), at values close to the optimal values for consumption (Crisosto et al., 1994). The increase in TSS in fruits submitted to deficit irrigation has been described in several deciduous fruits trees including plum (Intringliolo and Castel et al., 2010), peach (Gelly et al., 2004; Rahmati et al., 2014), pomegranate (Laribi et al., 2013), pear (López et al., 2011) and nectarine (Falagán et al., 2015a,b; López et al., 2016). This increase may be ascribed to the increase in organic acids synthesis in response to water stress as well as to osmotic adjustment mechanism (Pedrero et al., 2014), and is related to fruit flavour improvement that implies greater acceptance by the consumers, who perceives a sweeter flavour (Crisosto et al., 1994). Despite the increase in ${ }^{\circ}$ Brix in nectarines from T-Auto, the sensory evaluation did not clearly reflect this feature due to the astringent character of the cultivar studied (Fig. 4C) that mask the sweet flavour. In this sense, López et al. (2016) indicated that consumers perceived modest changes in fruit attributes, as those brought about water stress, that were not consistently reflected by fruit quality analysis obtained from analytical instruments (i.e. refractometer, colorimeter). Furthermore, the authors recommended the use of consumer panels as a more sensitive tool for deficit irrigation evaluation.

Another remarkable effect of water deficits on fruit quality attributes is the changes in skin colour due to its implications on fruit maturity (Falagán et al., 2015a,b; López et al., 2016). Thakur and Singh (2013) reported a more 
intense red colour in nectarine fruits undergoing water stress, which was mediated by the accumulation of bioactive compounds involved in the fruit ripening process. Moreover, the decrease in vegetative growth of deficit irrigated trees could allow fruit to be more exposed to sunlight (Conesa et al., 2019b). Nevertheless, the water deficits induced by the irrigation management in T-Double and T-Auto did not result in significant differences with respect to T-Single nectarines in fruit colour parameters (Table 3), which can be altered by the fruit browning occurring during storage. It should be noted that the consumers (from sensory panel) scored better the skin colour in nectarines from T-Auto than the other treatments at the end of the self-life period (Fig. 4D). Indeed, nectarine fruits from T-Auto were the best classified by consumers, although the overall sensory quality were above the limit of marketability in all the studied irrigation treatments (Fig. 4F).

In general, it could be noted that polyphenolic concentration (coloured and non-coloured flavonoids) was minimally affected by the irrigation treatments at the same storage period, which otherwise was not relevant from the nutritional point of view. Nevertheless, a significant effect on these bioactives composition could be observed when the storage temperature increases, as when the nectarine fruits were maintained at $15^{\circ} \mathrm{C}$ during 5 days a general flavonoids decrease was noticed (Table 3). This is due to the enzymatic oxidation of flavonoids, that take place after prolonged cold storage periods, by the loss of cellular compartmentalization (Thipyapong et al., 2007; Laribi et al., 2013), followed by a cooxidation with O-quinoines, in case of anthocyanins (Kader et al., 2002).

The obtained results indicate that these fruits could be a good source of bioactive compounds, mainly due to the anthocyanins (approximately half of the total concentration of flavonoids), even if these compounds are only present in the epidermal cells (Agati et al., 2012), representing less than 5\% f.w. Taking this into account, nectarine fruits could be considered similar to other fruits with interesting nutritional properties (De Pascual-Teresa et al., 2010; Alrawaiq and Abdullah, 2014).

Regarding anthocyanins, it is worth mentioning that they are also responsible for the differences in colour, at the self-life storage period, due to the decrease observed in their concentration, well related to chrome value (Table 3), rendering a darker colour fruit (De Pascual-Teresa et al., 2010).

During the storage experiment $\left(10\right.$ days at $0{ }^{\circ} \mathrm{C}+5$ days at $\left.15{ }^{\circ} \mathrm{C}\right)$, nectarine fruits from the T-Auto treatment registered the highest levels of TSS and IM, which was motivated by a reduction in TA levels (Table 3). Moreover, nectarine fruits were affected by the time of storage. The observed changes, particularly when the temperature was increased to $15{ }^{\circ} \mathrm{C}$ during shelf-life period (Table 3), were due to the sugars and organic acids consumption as respiratory substrates in the fruits (Gelly et al., 2004), which is characteristic 
during fruit ripening and senescence of climacteric fruits such as nectarines and peaches (Crisosto and Kader, 2000).

Weight loss values were $\approx 6 \%$ in all treatments at the end of the cold storage plus self-life period, and the highest values were found in nectarine fruits from the T-Single (Table 4), which was also appreciated by consumers at the sensory panel (Fig. 4B). Falagan et al. (2015a) reported similar values of weight loss in nectarines during free air-storage. Furthermore, these authors found lower weight loss in nectarines from RDI trees, probably due to the formation of a thicker cuticle as a result of the water stress to which the trees were exposed the previous post-harvest season. This fact was also noticed in deficit irrigated peaches (Crisosto et al., 1994; Falagán et al., 2014), pomegranates (Laribi et al., 2013), and table grapes (Conesa et al., 2015). Mpelasoka et al. (2001) reported a lower incidence of fungal attacks in apple fruits due to the formation of this cuticle. Fernández-Trujillo and Artés (1997) pointed out that the initial chilling injury were associated to a decreased in the $\mathrm{C}_{2} \mathrm{H}_{4}$ production in peach and nectarine fruits. Our results showed a lower incidence of fungal attacks and chilling injury in nectarines fruits from $\mathrm{T}$ Double and T-Auto treatments (Fig. 5E).

In conclusion, the irrigation scheduling based on real-time soil water content threshold values, with capacitance probes (T-Auto treatment) supposed a water saving of $43 \%$ without compromising yield, fruit size and bioactive compounds composition of nectarine fruits, while increasing $(\approx 34 \%)$ the WUE, compared with irrigation scheduling based on ETc. Also, an enhanced TSS levels and best consumer acceptance after cold storage was found in nectarine fruits from T-Auto. The irrigation design using two lines of emitters (T-Double) did not provide any clear advantage in terms of fruit production and quality with respect to the one-single line of emitters (T-Single). The use of precise sensor-based agronomic criteria could be a promising irrigation strategy in areas with scarce water resources threatened by climate change.

\section{ACKNOWLEDGEMENTS}

This research was supported by National Plan-FEDER (AGL2013-49047-C02-2R, AGL2016-77282-C03-1R and PID2019-106226RB-C2-1) and Seneca Foundation of Region of Murcia (19903/GERM/15) projects. Conesa M.R. acknowledges the postdoctoral financial support received from the Juan de la Cierva program (FJCI -2017 -32045).

\section{REFERENCES}

Abrisqueta, I., Vera, J., Tapia, L., Abrisqueta, J., Ruiz-Sánchez, M. 2012. Soil water content criteria for peach trees water stress detection during the 
postharvest period. Agric. Water Manage. 104, 62-67.

Abrisqueta, I., Abrisqueta, J., Tapia, L., Munguía, J., Conejero, W., Vera, J., Ruiz-Sánchez, M.C. 2013. Basal crop coefficients for early-season peach trees. Agric. Water Manage. 121, 158-163.

Abrisqueta, I., Conejero, W., López-Martínez, L., Vera, J., Ruiz-Sánchez, M.C. 2017. Root and aerial growth in early-maturing peach trees under two crop load treatments. Span. J. Agric. Res. 15 (2), e0803.

Agulló, V., Villaño, D., García-Viguera, C., Domínguez-Perles, R. 2020. Anthocyanin metabolites in human urine after the intake of new functional beverages. Molecules 25, e371.

Allen, R.G., Pereira, L.S., Raes, D., Smith, M. 1998. Crop Evapotranspiration: Guidelines for Computing Crop Water Requirements; Food and Agriculture Organization of the United Nations: Rome, Italy.

Alrawaiq, N.S., Abdullah, A.N. 2014. A review of flavonoid quercetin: metabolism, bioactivity and antioxidant properties. Inter. J. Pharm. Tech. Res. 6 (3), 933-941.

Ayars, J.E., Bucks, D.A., Lamm, F.R., Nakayama, F.S. 2007. Introduction. In: Lamm F.R, Ayars J.E, Nakayama F.S (Eds). Microirrigation for Crop Production, Vol. 13: Development in Agricultural 416 Engineering, Elsevier: Amsterdam; pp. 1-2.

Balsalobre, N., Koptsyukh, E., Ruiz-Sánchez, M.C., Vera, J., Conejero, W. Nicolás, M.J. 2018. Riego deficitario y raíces de nectarinos. V Congreso IDIES “I+D en Institutos de Enseñanza Secundaria" Murcia, 26 junio 2018. ISBN: 97884-09-03063-7, Academia de Ciencias de la Región de Murcia, Spain, pp. 7-8.

CIHEAM. 2010. The CIHEAM watch letter. Int. Center Adv. Mediterr. Agron. Stud. 12, pp. 1-12.

Chalmers, D.J., Mitchell, P.D., Van Heek, L. 1981. Control of peach tree growth and productivity by regulated water supply, tree density and summer pruning. J. Am. Soc. Hortic. Sci. 106, 307-312.

Conesa, M.R., García-Salinas, M.D., de la Rosa, J.M., Fernández-Trujillo, J.P., Domingo, R., Pérez-Pastor, A. 2014. Effects of deficit irrigation applied during fruit growth of late mandarin trees on quality harvest, chilling storage and subsequent shelf-life. Sci Hort. 165, 344-351.

Conesa, M.R., Martínez-López, L., Conejero, W., Vera, J., Ruiz-Sánchez, M.C. 2019a. Summer pruning of early-maturing Prunus persica: Water implications. Sci. Hort. 256, e108539.

Conesa, M.R., Conejero, W., Vera, J., Ramírez-Cuesta, J.M., Ruiz-Sánchez, M.C. 2019b. Terrestrial and remote indexes to assess moderate deficit irrigation in early-maturing nectarine trees. Agronomy 9 (10), e630.

Confederación Hidrográfica del Segura. 2020. https://www.chsegura.es/chs/index.html (accessed on 26 May 2020). 
Crisosto, C.H., Johnson, R.S., Luza, J.G., Crisosto, G.M. 1994. Irrigation regimes affect fruit soluble solids concentration and rate of water loss of 'O'Henry' peaches. HortScience 29, 1169-1171.

Crisosto, C.H., Kader, A.A. 2000. Plum and fresh prune postharvest quality maintenance guidelines. Handbook of fruits and fruit processing. Ed. By. YH. Hyi. 553-554 pp.

De la Rosa, J.M., Domingo, R., Gómez-Montiel, J., Pérez-Pastor, A. 2015. Implementing deficit irrigation scheduling through plant water stress indicators in early nectarine trees. Agric. Water Manage. 152, 207-216.

De la Rosa, J.M., Conesa, M.R., Domingo, R., Aguayo, E., Falagán, E., Pérez-Pastor, A. 2016. Combined effects of deficit irrigation and crop level on early nectarine trees. Agric. Water Manage. 170, 120-132.

De Pascual-Teresa, S., Moreno D.A., Garcia- Viguera, C. 2010. Flavanols and anthocyanins in cardiovascular health. A review of current evidences. Int. J. Molec. Sci. 11, 1679-1703.

Di Vaio, C., Marallo, N., Graziani, G., Ritieni, A., Di Matteo, A. 2015. Evaluation of fruit quality, bioactive compounds and total antioxidant activity of flat peach cultivars. J. Sci. Food Agric. 95, 2124-2131.

Domínguez-Niño, J.M., Oliver-Manera, J., Girona, J., Casadesús, J. 2020. Differential irrigation scheduling by an automated algorithm of water balance tuned by capacitance-type soil moisture sensors. Agric. Water Manage. 228, e105880.

Dodds, G.T., Brown, J.W., Ludford, P.M. 1991. Surface colour changes of tomato and other solanaceous fruit during chilling. J. Amer. Soc. Hort. Sci. 116 (3), 482-490.

European Union. Commission Regulation (EC) No 1221/2008 of 5 December (2008). Amending Regulation (EC) No 1580/2007 laying down implementing rules of Council Regulations (EC) No 2200/96, (EC) No 2201/96 and (EC) No 1182/2007 in the fruit and vegetable sector as regards marketing standards. Off. J. Eur. Union. 51, 80.

Evett, S.R., Tolk, J.A., Howell, T.A. 2006. Soil profile water content determination: sensor accuracy, axial response, calibration, temperature, dependence and precision. Vadose Zone J. 5, 894-907.

Falagán, N., Artés, F., Gómez, P.A., Artés-Hernández, F., Conejero, W., Aguayo, W. 2014. Deficit irrigation strategies combine with controlled atmosphere preserve quality in early peach. Food Sci. Technol. Intern. 21 (7), 547-556.

Falagán, N., Artés, F., Artés-Hernández, F., Gómez, P.A., Pérez-Pastor, A., Aguayo, E. 2015a. Comparative study on postharvest performance of nectarines grown under regulated deficit irrigation. Post. Biol. Technol. 110, 2432. 
Falagán, N., Artés, F., Gómez, P.A., Artés-Hernández, F., Gómez, P.A., Pérez-Pastor, A., de la Rosa, J.M., Aguayo, E. 2015b. Combined effects of deficit irrigation and fresh-cut processing on quality and bioactive compounds of nectarines. Hort. Sci. 42(3), 125-31.

Falagán, N., Artés, F., Gómez, P.A., Artés-Hernández, F., Pérez-Pastor, A., de la Rosa, J.M., Aguayo, E. 2016. Individual phenolics and enzymatic changes in response to regulated deficit irrigation and storage conditions of extra early nectarine. J. Amer. Soc. Hort. Sci. 141(3), 222-232.

Fereres, E., Soriano, M.A. 2007. Deficit irrigation for reducing agricultural water use. J. Exp. Bot. 58, 435 147-159.

Fernández-García, I., Lecina, S., Ruiz-Sánchez, M.C., Vera, J., Conejero, W., Conesa, M.R., Dominguez A., Pardo, J.J., Léllis, B.C., Montesinos, P. 2020. Trends and challenges in irrigation scheduling in the semi-arid area of Spain. Water 12 (3), e785.

Fernández-Trujillo, J.P., Artés, F. 1997. Keeping quality of cold stored peaches using intermittent warming. Food Res. Intern. 30, 441-450.

Gelly, M., Recasens, I., Girona, J., Mata, M., Arbones, A., Rufat, J., Marsal, J. 2004. Effects of stage II and postharvest deficit irrigation on peach quality during maturation and after cold storage. J. Sci. Food Agric. 84, 561-568.

Génard, M., Bertín, N., Borel,C., Bussiéres, P., Gautier, H., Habib, R. Léchaudel, M., Lecomte, A., Lescourret, F., Lobit, P., Quilot, B. 2007. Towards a virtual fruit focusing on quality: modelling features and potential uses. J. Exp. Bot. 58, 917-928.

Girona, J., Gelly, M., Mata, M., Arbonés, A., Rufat, J., Marsal, J. 2005. Peach tree response to single and combined deficit irrigation regimes in deep soils. Agric. Water Manage. 72, 97-108.

Girona, J., Fereres, E., 2012. Peach. In: Steduto, P., Hsiao, T.C., Fereres, E., Raes, D. (Eds.), Crop Yield Response to Water. FAO Irrigation and Drainage Paper No. 66, Rome, pp. 266-280.

Gironés-Vilaplana, A., Mena, P., García-Viguera, C., Moreno, D.A. 2012. A novel beverage rich in antioxidant phenolics: Maqui berry (Aristotelia chilensis) and lemon juice. LWT-Food Sci. Tech. 47, 279-286.

Guttormsen, G. 1969. Accumulation of salts in the sub-irrigation of pot plants. Plant Soil. 31, 425-438

Hsiao, T.C. 1990. Measurement of tree water status. In: Steward, B. A., Nielsen, D.R. (Eds), Irrigation of Agricultural Crops. Agronomy Monograph No.30. American Society of Agronomy. Madison. WI. pp 243-279.

Intrigliolo, D.S., Castel, J.R. 2010. Response of plum trees to deficit irrigation under two crop levels: tree growth, yield and fruit quality. Irrig. Sci. $28,525-534$. 
Kader, F., Irmouli, M., Nicolas, J.P., Metche, M. 2002. Involvement of blueberry peroxidase in the mechanisms of anthocyanin degradation in blueberry juice. J. Food Sci. 67 (3), 910-915.

Katerji, N., Mastrorilli, M., Rana, G. 2008. Water use efficiency of crops cultivated in the Mediterranean regions: Review and analysis. Europ. J. Agron. 28 (4), 493-507.

Kyriacou, M.C., Rouphael, Y. 2018. Towards a new definition of quality for fresh fruits and vegetables. Sci. Hort. 234, 463-469.

Laribi, A.I., Palou, L., Intrigliolo, D.S., Nortes, P.A., Rojas-Argudo, C., Taberner, V., Bartual, J., Pérez-Gago, M.B. 2013. Effect of sustained and deficit irrigation on fruit quality of pomegranate cv. 'Mollar de Elche' at harvest and during cold storage. Agric. Water Manage. 125, 61-70.

Legua, P, Hernández, F., Día-Mula, H.M., Valero, D., Serrano, M. 2011. Quality, bioactive compounds and antioxidant activity of new flat-type peach and nectarine cultivars: a comparative study. J. Food Sci. 76 (5), 729-735.

López, G., Larrigaudiere, C., Girona, J., Behboudian, M.H., Marsal J. 2011. Fruit thinning in 'conference' pear grown under deficit irrigation: implications for fruit quality at harvest and after cold storage. Sci. Hort. 129 (1), $64-70$.

López, G., Echeverria, G., Bellvert, J., Mata, M., Behboudian, M.H., Girona, J., Marsal, J. 2016. Water stress for a short period before harvest in nectarine: Yield, fruit composition, sensory quality, and consumer acceptance of fruit. Sci. Hort. 211, 1-7

Millán, S., Casadesús, J., Campillo, C., Moñino, M.J., Prieto, M.H. 2019. Using soil moisture sensors for automated irrigation scheduling in a plum crop. Water 11, e2061.

Million, J., Yeager, T., Larsen, C. 2007. Water use and fertilizer response of azalea using several no-leach irrigation methods. HortTech. 17, 21-25.

Mounzer, O.H., Conejero, W., Nicolás, E., Abrisqueta, I., García-Orellana, Y., Tapia, L.M., Vera, J., Abrisqueta, J.M., Ruiz-Sánchez, M.C. 2008. Growth pattern and phenological stages of early maturing peach trees under a Mediterranean climate. HortScience 43 (6), 1813-1818.

Mpelasoka, B.S., Behboudian, M.H., Mill, T.M. 2001. Effects of deficit irrigation on fruit maturity and quality of 'Braebourn' apple. Sci. Hort. 90, 279290.

Myers, B.J. 1988. Water stress integral-a link between short-term stress and long-term growth. Tree Physiol. 4, 315-323.

Naor, A., Stern, R., Peres, M., Greenblat, Y., Gal, Y., Flaishman, M.A. 2005. Timing and severity of postharvest water stress affect following-year productivity and fruit quality of field-grown 'Snow Queen' nectarine. J. Am. Soc. Hortic. Sci. 130, 806-812. 
Ondrasek, G., Romic, D., Romic, M., Tomic, F., Mustac, I. 2008. Salt distribution in peat substrate grown with melon (Cucumis melo L.). Acta Hortic. 779, 307-312.

Pedrero, F., Maestre-Valero, J.F., Mounzer, O., Alarcón, J.J., Nicolás, E. 2014. Physiological and agronomic mandarin trees performance under saline reclaimed water combined with regulated deficit irrigation. Agric. Water Manage. 146, 228-237.

Pérez-Pastor, A., Ruiz-Sánchez, M.C., Martínez, J.A., Nortes, P.A., Artés, F. y Domingo, R. 2007. Effect of deficit irrigation on apricot fruit quality at harvest and during storage. J. Sci. Food Agric. 87, 2409-2415.

Pérez-Pastor, A., Ruiz-Sánchez, M.C., Conesa, M.R., 2016. Drought stress effect on woody tree yield. In: Ahmad, P. (Ed.), 'Water Stress and Crop Plants: A Sustainable Approach Vol.2. John Wiley \& Sons Ltd., UK, pp. 356-374 ISBN: 9781119054368. Chapter 22. pp. 356-374.

Rahmati, M., Vercambre, G., Davarynejad, G.H., Bannayan, M., Azizi, M., Génard, M. 2014. Water scarcity conditions affect peach fruit size and polyphenol contents more severely than other fruit quality traits. J. Sci. Food Agric. 95, 1055-1065.

Ruiz-Sánchez M.C., Domingo, R., Castel, J.R. 2010. Review. Deficit irrigation in fruit trees and vines in Spain. Span. J. Agric. Res. 8 (S2), 5-20.

Ruiz-Sánchez, M.C., Abrisqueta, I., Conejero, W., Vera, J. 2018. Deficit irrigation management in early-maturing peach crop. In: Water Scarcity and Sustainable Agriculture in Semiarid Environment. Tools, Strategies, and Challenges for Woody Crops. ISBN 978-0-12-813164-0. Elsevier. Chapter 6. Pp. 111-126.

Samadianfard, S., Sadraddini, A.A., Nazemi, A.H., Provenzano, G., Kisi, O. 2012. Estimating soil wetting patterns for drip irrigation using genetic programming. Span. J. Agric. Res. 1155-1166.

Thipyapong, P., Stout, M.J., Attajarusit, J. 2007. Functional analysis of polyphenol oxidases by antisense/sense technology. Molecules 12 (8), 15691595.

Thakur A., Singh Z. 2013. Deficit irrigation in nectarine: Fruit quality, return bloom and incidence of double fruits. Europ. J. Hort. Sci. 78 (2), 67-75.

Vera, J., Abrisqueta, I., Abrisqueta, J.M., Ruiz-Sánchez M.C. 2013. Effect of deficit irrigation on early-maturing peach tree performance. Irrig. Sci. 31, 747-757.

Vera, J., de la Peña, J.M. 1994. FERTIGA: Programa de Fertirrigación de Frutales; CEBAS-CSIC: Murcia, Spain, pp. 69.

Vera, J., Conejero, W., Conesa, M.R., Ruiz-Sánchez, M.C. 2019. Irrigation factor approach based on soil water content: A nectarine orchard case study. Water (11), e589. 
Zhu, X.Q., Chen, X.Y., Luo, Y., Guo L.Y. 2005. First report of Monilinia fructicola on peach and nectarine in China. Plant Pathol. 54(4), 575. 